\title{
PEMODELAN MATEMATIS HUBUNGAN KADAR AIR TEPUNG DENGAN VARIABEL PROSES PADA PENGERINGAN MEKANIS TEPUNG KASAVA MENGGUNAKAN PNEUMATIC DRYER
}

\author{
Mathematical Modelling of The Relationship between Moisture Content of The Flour and Process Variables in \\ Mechanical Drying of Cassava Flour Using Pneumatic Dryer \\ Yus Witdarko', Nursigit Bintoro², Bandul Suratmo², Budi Rahardjo² \\ ${ }^{1}$ Jurusan Teknik Pertanian, Fakultas Pertanian, Universitas Musamus, Jl. Kamizaun, Mopah Lama, Merauke 99611 \\ ${ }^{2}$ Jurusan Teknik Pertanian, Fakultas Teknologi Pertanian, Universitas Gadjah Mada, \\ Jl. Flora No. 1, Bulaksumur, Yogyakarta 55281 \\ Email: buluhbulan@gmail.com
}

\begin{abstract}
ABSTRAK
Kadar air bahan $(\mathrm{Ka})$ merupakan variabel yang paling penting dalam mengevaluasi kinerja proses pengeringan bahan, sehingga kemampuan untuk memprediksi Ka dalam proses pengeringan akan menjadi sangat penting. Penelitian ini bertujuan untuk memformulasikan hubungan matematis antara berbagai variabel proses pengeringan secara pneumatik dengan Ka akhir tepung ketela pohon dengan menerapkan analisis dimensi. Pada penelitian ini telah dirancang peralatan pneumatic drying dan dilakukan pengujian dengan berbagai macam variasi perlakuan seperti kapasitas input, temperatur udara pengering, dan kecepatan udara pengering. Berdasarkan hasil analisis data maka diperoleh hubungan antara Ka dengan variabel-variabel proses pengeringan sebagai berikut:

$$
K a=1,1968 \times 10^{-5} \cdot\left(\frac{\rho_{p r} D_{p r}^{3}}{Q_{i} \theta}\right)^{1.0121}\left(\frac{T_{u}}{T_{b o}}\right)^{-4.9698}\left(\frac{V_{u}}{D_{p r} \theta}\right)^{4.4752}
$$

Persamaan tersebut mempunyai nilai koefisien determinasi 0,722 sehingga besar kemungkinan untuk dapat digunakan sebagai alternatif dalam memprediksi kadar air tepung hasil pengeringan. Hasil uji sensitivitas menunjukkan bahwa dimensionless product yang paling berpengaruh terhadap nilai Ka adalah $\frac{T_{u}}{T_{b o}}$.
\end{abstract}

Kata kunci: Tepung kasava, pneumatic drying, analisis dimensi, kadar air

\section{ABSTRACT}

Moisture content of the materials $(\mathrm{Ka})$ is the most important variable in evaluating the performance of drying process, therefore the ability to predict moisture-content of the materials in the drying process is very important. The objective of this research was to formulate a mathematical relationship between various pneumatic drying process variables and the moisturecontent of the materials of cassava flour by applying dimensional analysis. In this research, a pneumatic drying equipment and test edit in wide varieties of treatments, such as the input capacity, drying air temperature, and drying air velocity. Based on the result of data analysis, it was obtained that the relationship between moisture content of the materials and the drying process variables could be expressed as follow

$$
K a=1,1968 \times 10^{-5} \cdot\left(\frac{\rho_{p r} D_{p r}^{3}}{Q_{i} \theta}\right)^{1.0121}\left(\frac{T_{u}}{T_{b o}}\right)^{-4.9698}\left(\frac{V_{u}}{D_{p r} \theta}\right)^{4.4752}
$$

This equation had 0,722 coefficient of determination, so that it could be used to predict the moisture content of cassava flour precisely. Sensitivity analysis indicated that the dimensionless product which had the largest effect on Ka was .

Keywords: Cassava flour, pneumatic drying, dimensional analysis, moisture content 


\section{PENDAHULUAN}

Pertumbuhan permintaan tepung terigu dari pasar domestik mencapai 6-7 \% per tahun (Asosiasi Produsen Tepung Indonesia, 2012). Pada tahun 2012, konsumsi terigu mencapai 5,05 juta metrik ton, tumbuh $7,6 \%$ dari tahun 2011 sebesar 4,75 juta metrik ton. (Asosiasi Produsen Tepung Indonesia 2013). Untuk mengurangi kebutuhan tepung terigu yang terus meningkat tersebut, perlu adanya upayaupaya untuk dapat mensubstitusi dengan tepung-tepung produksi lokal. Salah satu jenis yang paling potensial untuk mensubstitusi tepung terigu tersebut adalah tepung kasava.

Namun demikian berbagai kendala masih dihadapi dalam proses produksi tepung kasava. Tepung kasava termasuk pati yang diproduksi oleh industri umumnya telah menerapkan cara pengeringan mekanis. Perlu berbagai macam informasi ilmiah untuk meningkatkan proses pengeringan tepung kasava ini, mengingat proses pengeringan merupakan tahapan yang membutuhkan energi sangat besar dan mahal (Desrosier, 2008)

Pada beberapa industri kasava maupun pati telah diterapkan metode pengeringan secara pneumatik (flash drying). Pada cara pengeringan ini parutan atau hancuran kasava atau pati basah dihembuskan di dalam saluran pipa pengering vertikal dengan panjang tertentu, kemudian dipisahkan antara tepung kering dan udara dengan menggunakan cyclone yang dipasang di ujung saluran pipa pengering.

Berbagai macam variabel operasional proses pengeringan, mesin pengering, maupun bahan parutan kasava yang dikeringkan sangat menentukan sekali terhadap kualitas akhir tepung hasil pengeringan. Pada proses pengeringan bahan, umumnya variabel utama yang digunakan untuk mengevaluasi kinerja proses pengeringan tersebut adalah kadar air bahan hasil pengeringan.

Pada pengeringan tepung, disyaratkan oleh BSN (Badan Standardisasi Nasional 2012), bahwa kadar air akhir maksimal 12\%wb (SNI 01-2997-1996). Sedangkan menurutAfrianti (2000),Ka bahan pangan yang aman adalah $11 \%$ wb karena cendawan dapat tumbuh pada substrat bahan pangan berkadar air serendah-rendahnya $12 \%$ wb sedang bakteri dan khamir tumbuh pada kadar air lebih dari $30 \%$ wb. Pada Ka yang rendah tepung akan aman untuk disimpan tidak mudah berjamur maupun diserang oleh serangga. Oleh karena itu, sangat penting sekali untuk dapat menjamin bahwa proses pengeringan dapat berjalan dengan baik sehingga benarbenar dapat dihasilkan suatu upaya untuk menghubungkan antara variabel-variabel proses pengeringan dengan kadar air bahan hasil pengeringan. Zare dkk. (2012), melakukan pengeringan biji canola dengan memvariasi kelembaban udara pengering $0,0005-0,02 \mathrm{~kg} / \mathrm{kg}^{\prime}$ pada temperatur tetap $45^{\circ} \mathrm{C}$. Hasil penelitian memberikan hubungan matematis antara ratio (MR) dengan waktu pengeringan (t), konstanta pengeringan $\left(a, b, k_{1}\right.$, dan $k_{2}$ ), data experiment (exp) dalam bentuk persamaan sebagai berikut:

$$
M R=a \exp -k_{1} t+b \exp -k_{2} t
$$

Dimana, $\mathrm{a}=2,834-0,563 \operatorname{Ln}(\mathrm{T}) 8,752 \mathrm{H} ; \mathrm{k}_{1}=0,079-0,018$ $\operatorname{Ln}(\mathrm{T}) 0,011 \mathrm{H} ; \mathrm{b}=-1,83+0,5621 \mathrm{Ln}(\mathrm{T})-8,978 \mathrm{H} ; \mathrm{k}_{2}=0,542+$ $0,188 \operatorname{Ln}(\mathrm{T})-1,38 \mathrm{H}$

Goula danAdamopoulos (2005), melakukan pengeringan serbuk tomat dengan memvariasi temperatur udara pengering dan laju aliran udara.Hasil penelitian memberikan hubungan matematis antara kadar air (M) dengan temperatur udara pengering $\left(\mathrm{T}_{\text {inlet }}\right)$ dan laju udara pengering $\left(\mathrm{Q}_{\mathrm{a}}, \mathrm{Q}_{\mathrm{c}}\right)$,dalam bentuk persamaan berikut:

$$
\begin{aligned}
M= & 124-186 \cdot T_{\text {inlet }}-0,681 \cdot Q_{a}+0,00115 \cdot Q_{c}+0 \\
& 0,000003 \cdot Q_{c}^{2}-0,00213 \cdot T_{\text {inlet }} \cdot Q_{a}
\end{aligned}
$$

Selanjutnya Bunyawanichakul dkk. (2007), melakukan pengeringan pnematik bijian beras dengan memvariasi diameter pipa pengering $0,102-0,203 \mathrm{~m}$, kapasitas input bijian $0,5-1 \mathrm{~kg} / \mathrm{s}$, dan kecepatan udara pengering $15-23 \mathrm{~m} / \mathrm{s}$ pada temperatur udara pengering tetap $110{ }^{\circ} \mathrm{C}$. Hasil penelitian diberikan hubungan matematis antara kadar air $(\mathrm{M})$ dengan kelembaban relatif( $(\mathrm{RH})$ dan temperatur bijian padi $\left(\mathrm{T}_{\mathrm{p}}\right)$ sebagai berikut:

$$
M=\frac{1}{100}\left[\frac{\ln (1-R H)}{-3,146 \times 10^{-6} T_{p}}\right]^{\frac{1}{2,464}}
$$

Belum ada persamaan matematis yang menghubungkan antara $\mathrm{Ka}$ dengan variabel-variabel proses pengeringan untuk tepung kasava. Oleh karena itu, perlu dicari hubungan matematis antara Ka bahan tepung hasil pengeringan dengan kondisi proses pengeringannya, sehingga dapat digunakan untuk memprediksi kadar air tepung kasava pada proses pengeringan.

Analisis dimensi mempunyai langkah-langkah yang sederhana, tetapi kemanfaatannya sangat besar yang memungkinkan peneliti merancang peralatan dalam skala kecil, tidak mahal harganya dan memungkinkan dilaksanakan di laboratorium.Lebih lanjut dengan analisis dimensi ini proses perancangan mesin pengering pneumatik akin dapat dilakukan dengan teliti dan terarah. Tujuan penelitian ini adalah untuk menghubungkan $\mathrm{Ka}$ bahan tepung dengan beberapa variabel proses pengeringan pneumatik dengan menggunakan metode analisis dimensi. Dengan adanya hubungan matematis ini maka akan sangat mempermudah baik bagi desainer alat mesin dalam mengkonstruksi mesin pengering pneumatik maupun operator mesin pengering 
untuk mendapatkan kadar air tepung yang dikeringkan agar memenuhi standar Ka yang ditetapkan.

\section{METODE PENELITIAN}

Analisis dimensi merupakan salah satu carayang dapat dgunakan untuk mendapatkan hubungan kuantitatif antara produk tepung, mesin pengering serta proses pengeringan. Pada penelitian ini untuk mencari hubungan matematis antara Ka tepung hasil pengeringan dengan variabel-variabel proses pengeringan telah dipilih beberapa variabel yang diperkirakan mempunyai hubungan tertentu. Tabel 1 adalah beberapa independen variabel yang diduga mempunyai hubungan dengan Ka tepung hasil pengeringan secara pneumatik.

Tabel 1. Independen dan dependen variabel pada analisis dimensi kadar air tepung

\begin{tabular}{llll}
\hline Nama variabel & Simbol & Satuan & Dimensi \\
\hline Independen variabel & & & \\
a. Densitas partikel & $\rho_{\mathrm{pr}}$ & $\mathrm{Kg} / \mathrm{m}^{3}$ & $\mathrm{ML}^{-3}$ \\
b. Kapasitas input bahan & $\mathrm{Q}_{\mathrm{i}}$ & $\mathrm{Kg} / \mathrm{s}$ & $\mathrm{MT}^{-1}$ \\
c. Temperatur bahan awal & $\mathrm{T}_{\mathrm{bo}}$ & ${ }^{\circ} \mathrm{C}$ & $\mathrm{O}$ \\
d. Temperatur udara & $\mathrm{T}_{\mathrm{u}}$ & ${ }^{\circ} \mathrm{C}$ & $\mathrm{O}$ \\
e. Diameter partikel & $\mathrm{D}_{\mathrm{pr}}$ & $\mathrm{m}$ & $\mathrm{L}$ \\
f. Waktu pengeringan & $\theta$ & $\mathrm{s}$ & $\mathrm{T}$ \\
g. Kecepatan udara pengering & $\mathrm{V}_{\mathrm{u}}$ & $\mathrm{m} / \mathrm{s}$ & $\mathrm{LT}-1$ \\
Dependen variabel & & & \\
a. Kadar air & $\mathrm{Ka}$ & - & - \\
\hline
\end{tabular}

Dari variabel-variabel tersebut dapat ditulis hubungan fungsional sebagai berikut:

$$
\begin{aligned}
& K a=f\left(\rho_{p r}, Q_{i}, T_{b o}, T_{u}, D_{p r}, \theta, V_{u}\right) \\
& \pi=\rho_{p r}^{k 1} Q_{i}^{k 2} T_{b o}^{k 3} T_{u}^{k 4} D_{p r}^{k 5} \theta^{k 6} V_{u}^{k 7}
\end{aligned}
$$

Terdapat 8 variabel dengan 4 dimensi dasar, maka menurut teori Buckhingham $\pi$ (Langhaar, 1967) akan menghasilkan 4 dimensionless product $(\pi)$. Dengan memberikan nilai-nilai tertentu pada $\mathrm{k} 1, \mathrm{k} 3$ dan $\mathrm{k} 7$ maka diperoleh:

$$
\begin{aligned}
& \pi_{1}=\mathrm{Ka} \\
& \pi_{2}=\frac{\rho_{p r} \cdot D_{p r}^{3}}{Q_{i} \cdot \theta} \\
& \pi_{3}=\frac{T_{u}}{T_{b o}} \\
& \pi_{4}=\frac{V_{u}}{D_{p r .} \theta}
\end{aligned}
$$

Nilai-niai $\pi$ kemudian disusun dalam bentuk hubungan fungsional sebagai berikut:

$$
K a=C \cdot\left(\frac{\rho_{p r} D_{p r}^{3}}{Q_{i} \theta}\right)^{a}\left(\frac{T_{u}}{T_{b o}}\right)^{b}\left(\frac{V_{u}}{D_{p r} \theta}\right)^{c}
$$

Adapun konstanta C, a, b, c dapat ditentukan berdasarkan data-data hasil penelitian yang dilakukan dengan merubah persamaan (10) dalam bentuk log.

\section{Bahan}

Bahan penelitian berupa kasavajenis putih yang diperoleh dari pasar Telo dan pasar Colombo, Yogyakarta sebanyak 200 kg.Kasava kemudian dikupas dan dicuci selanjutnya diparut dengan mesin pemarut.Untuk mengurangi air dalam parutan ketela pohon, selanjutnya dilakukan pengempaan dengan mesin penekan hidrolik.Pengempaan dilakukan untuk setiap 1000 gram berat parutan dengan tekanan $50 \mathrm{~kg} / \mathrm{cm}^{2}$ selama 10 menit.Parutan kasava padat dari hasil pengempaan dihancurkan lagi secara manual menjadi tepung basah. Hasil tepung basah tersebut kemudian diayak dengan ayakan ukuran 60 mesh dan 80 mesh. Tepung basah yang lolos dari ayakan 60 mesh namun tertinggal di ayakan 80 mesh digunakan sebagai sampelbahan yang akandikeringkan dan menurut Stoess (1983), ukuran tepung tersebut termasuk kelas fine materials. Sampel tepung basah tersebut mempunyai kadar air rata-rata sebesar 40 - $42 \%$ wb. Proses selanjutnya, tepung hasil pengayakan tersebut dikeringkan dengan flash dryer yang telah dikonstruksi dalam dua kali proses.

\section{Alat}

Gambar 1 menunjukkan mesin pengering pneumatik yang telah dikonstruksi untuk keperluan penelitian ini. Sumber pemanas menggunakan gas LPG dengan burner dan regulator tekanan tinggi yang dapat diatur suhunya dengan mengatur putaran keran pada regulator maupun burner. Burner ditempatkan di dalam suatu kotak tungku persegi dengan penutup aliran udara masuk yang dapat diatur lebar bukaannya. Pengaturan kecepatan aliran udara pengering dilakukan dengan mengatur lebar bukaan penutup tungku tersebut.Fan penghembus menggunakan blower sirocco tipe sentrifugal 735 watt yang mengisap udara panas dan menyalurkannya ke dalampipa pengering. Pemasukan bahan tepung basah dilakukan lewat feeding hopper yang dilengkapi dengan screw conveyor dan blower kecil 367 watt sebagai pendorong bahan. Feeding hopper ini dipasang pada bagian pipa lurus di atas centrifugal blower penghembus. Laju pemasukan bahan yang dikeringkan dapat diatur dengan mengatur kecepatan putaran screw conveyor.

Proses pengeringan terjadi disepanjang saluran pipa pengering dan untuk memisahkan antara udara panas, dust dan tepung kering dilakukan di dalam unit cyclone yang ditempatkanpada ujung pipa pengering. 


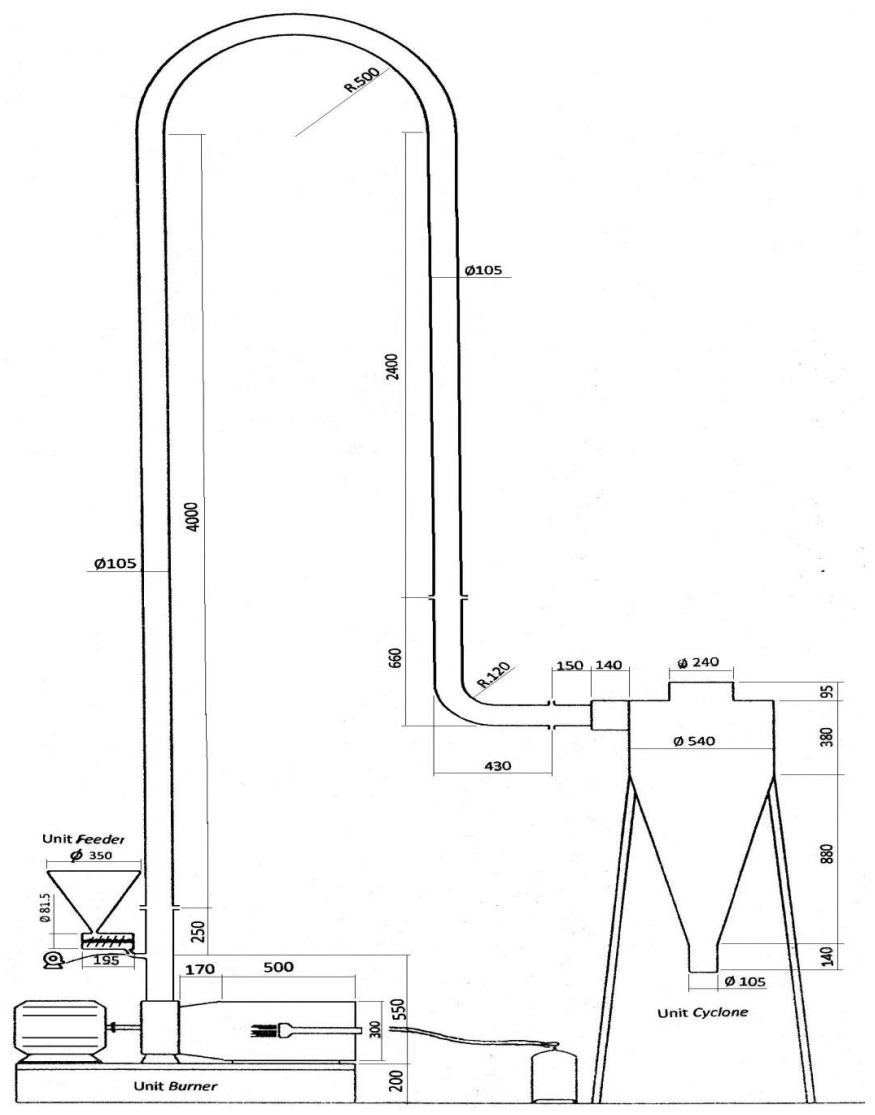

Gambar 1. Peralatan pengering mekanis tipe pneumatik (flash dryer)

\section{Prosedur Penelitian}

Penelitian dimulai dengan menghidupkan mesin pengeringflash dryer, kemudian mengatur suhu pengeringan, kecepatan aliran udara pengering dan laju input bahan sesuai dengan yang ditetapkan. Pada penelitian ini temperatur udara pengering divariasi sebanyak tiga tingkat yaitu 145 ${ }^{\circ} \mathrm{C}, 160{ }^{\circ} \mathrm{C}$, dan $175{ }^{\circ} \mathrm{C}$. Demikian juga kecepatan aliran udara pengering divariasi dalam tiga tingkat yaitu $17,12 \mathrm{~m} / \mathrm{s}$, $18,10 \mathrm{~m} / \mathrm{s}$, dan $19,29 \mathrm{~m} / \mathrm{s}$. Adapun laju input bahan yang dikeringkan divariasi $0,0371 \mathrm{~kg} / \mathrm{s}, 0,0509 \mathrm{~kg} / \mathrm{s}$, dan 0,0616 $\mathrm{kg} / \mathrm{s}$. Data-data lain yang dibutuhkan untuk kepentingan analis dimensi seperti $\rho_{\mathrm{pr}}, \mathrm{D}_{\mathrm{pr}}$, dan $\mathrm{T}_{\mathrm{bo}}$ dibuat tetap masingmasing $1266 \mathrm{~kg} / \mathrm{m}^{3}, 0,2596 \mathrm{~mm}$, dan $30,43{ }^{\circ} \mathrm{C}$. Sedangkan nilai $\theta$ (waktu pengeringan) diukur secara langsung pada saat proses pengeringan berjalan.kondisi lingkungan suhu $29^{\circ} \mathrm{C}-$ $30{ }^{\circ} \mathrm{C}$ dan kelembaban relatif $69 \%-70 \%$.

\section{HASIL DAN PEMBAHASAN}

Berdasarkan data-data yang telah dikumpulkan selama pelaksanaan penelitian, maka dapat dilakukan analisis dimensi untuk menentukan nilai-nilai konstanta persamaan yang telah diformulasikan.
Menggunakan bentuk log dari persamaan (10) maka dapat diperoleh nilai-nilai konstanta $\mathrm{C}, \mathrm{a}, \mathrm{b}$, dan c yaitu $1,1968 \times 10^{-5}, 1,0121,-4,9698$, dan 4,4752, sehingga hubungan matematis antara $\mathrm{Ka}$ dengan variabel-variabel proses pengeringan dapat ditulis seperti pada persamaan (11).

$$
K a=1,1968 \times 10^{-5} \cdot\left(\frac{\rho_{p r} D_{p r}^{3}}{Q_{i} \theta}\right)^{1.0121}\left(\frac{T_{u}}{T_{b}}\right)^{-4.9698}\left(\frac{V_{u}}{D_{p r} \theta}\right)^{4.4752}
$$

Dari persamaan ini dapat dilihat hubungan antara masing-masing dimensionless product dengan $\mathrm{Ka}$ bahan hasil pengeringan. Hubungan $\left(\frac{\rho_{p r} D_{p r}^{3}}{Q_{s} \theta}\right)$ terhadap Ka dimana pada penelitian ini $\left(\frac{\rho_{p r} D_{p r}^{3}}{Q_{a} \theta}\right)$ divariasi dari $-7,280--7,500$. Dapat diketahuibahwa pengaruh $\mathrm{Q}_{\mathrm{i}}$ dan $\mathrm{D}_{\mathrm{pr}}$ terhadap $\mathrm{Ka}$ saling berlawanan dimana bila $Q_{i}$ naik, maka Ka akan turun, sebaliknya bila $\mathrm{D}_{\mathrm{pr}}$ naik, maka Ka akan naik. Dengan memperhatikan grafik Gambar 2 tersebut dapat diketahui bahwa efek $D_{p r}$ terhadap Ka lebih besar dari pada efek $Q_{i}$ terhadap Ka, sehingga hubungan antara $\left(\frac{\rho_{r} r_{0}^{3} r}{\rho_{i} \theta}\right)$ dengan $\mathrm{Ka}$ membentuk garis linier dengan slope positif, yang berarti semakin besar diameter partikel maka Ka tepung yang dihasilkan akan semakin besar. Hal ini dapat dibuktikan dari hasil uji sensitivitas variabel $\mathrm{Q}_{\mathrm{i}}$ dan $\mathrm{D}_{\mathrm{pr}}$ terhadap $\mathrm{Ka}$ bahan. Ketika nilai $\mathrm{D}_{\mathrm{pr}}$ dinaikkan atau diturunkan sebasar $10 \%$, nilai Ka berubah rata-rata $38,23 \%$. Adapun ketika nilai $\mathrm{Q}_{\mathrm{i}}$ dinaikkan atau diturunkan $10 \%$, nilai Ka hanya berubah sebesar $25,21 \%$.

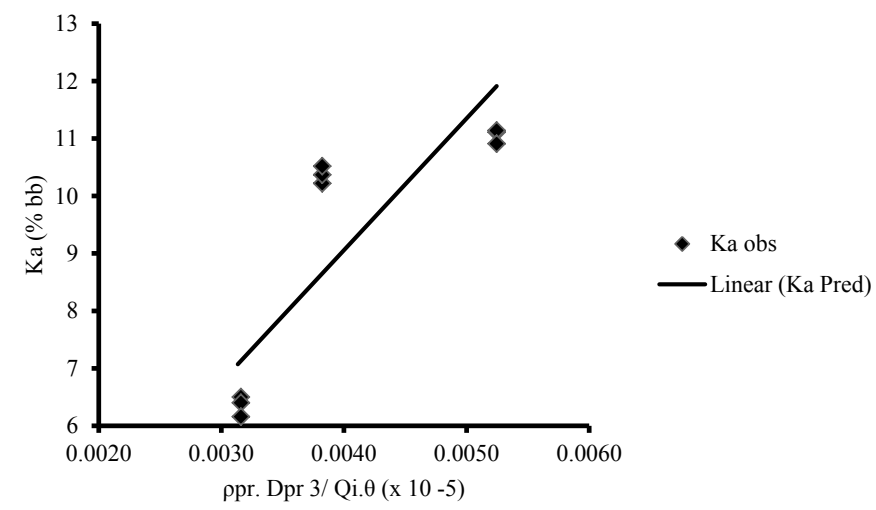

Gambar 2. Grafik hubungan $\rho_{\mathrm{pr}} \cdot \mathrm{D}_{\mathrm{pr}}{ }^{3} / \mathrm{Q}_{\mathrm{i}} \cdot \theta$ dengan $\mathrm{Ka}$

Hubungan rasio temperatur udara pengering terhadap temperatur bahan awal dengan kadar air tepung hasil pengeringan dimana pada penelitian ini $\left(\frac{T_{u}}{T_{b}}\right)$ divariasi dari 0,673-0,755 dapat dilihat pada Gambar 3. Semakin besar rasio $\left(\frac{T_{u}}{T_{b}}\right)$ menunjukkan bahwa perbedaan temperatur antara bahan dengan udara pengering semakin besar. Semakin besar perbedaan temperatur antara bahan dengan udara pengering, maka akan semakin meningkatkan transfer panas dari udara ke bahan, karena perbedaan temperatur merupakan driving force dari transfer panas. Semakin meningkatnya transfer panas, 
maka akan semakin besar kemampuannya untuk menguapkan air dari bahan, sehingga akan semakin menurunkan kadar air bahan yang dikeringkan.

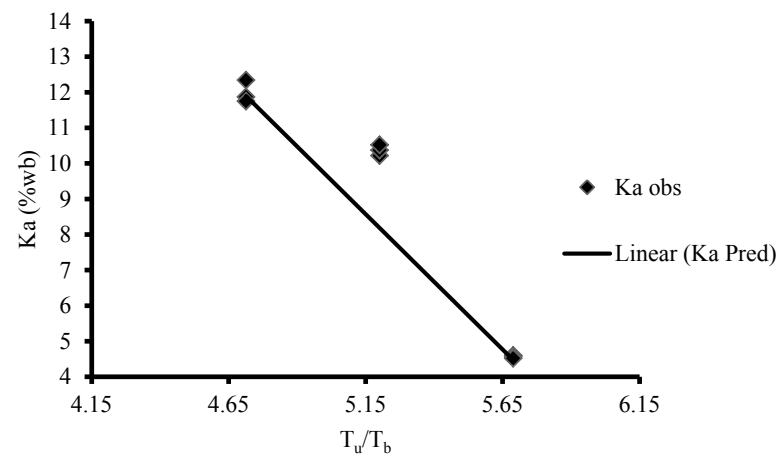

Gambar 3. Grafik hubungan antara $\mathrm{T}_{\mathrm{u}} / \mathrm{T}_{\mathrm{b}}$ dengan Ka

Hubungan antara dimensionless product $\frac{V_{u}}{D_{p r} \theta}$ dengan ka dapat dilihat pada Gambar 4 dimana pada penelitian ini $\left(\frac{v_{u}}{D_{p r} \theta}\right)$ divariasi dari 3,763 - 3,815. Bila ukuran diameter partikel bahan yang dikeringkan serta waktu pengeringan tetap, maka naiknya kecepatan aliran udara akan mengakibatkan peningkatan kadar air bahan yang dikeringkan. Hal ini disebabkan karena dengan meningkatnya kecepatan aliran udara, maka residence time (waktu tinggal) pemanasan bahan akan semakin singkat, sehingga $\mathrm{Ka}$ bahan akan semakin tinggi.

Untuk mengevaluasi pengaruh dimensionless product terhadap Ka maka telah dilakukan uji sensitivitas dengan menaikkan dan menurunkan masing-masing nilai dimensionless product tersebut $10 \%$.

Berdasarkan hasil uji sensitivitas diketahui bahwa secara berturut-turut dimensionless product yang paling berpengaruh terhadap nilai $\mathrm{Ka}$ adalah $\mathrm{T}_{\mathrm{u}} / \mathrm{T}_{\mathrm{bo}}, \mathrm{V}_{\mathrm{u}} / \mathrm{D}_{\mathrm{pr}}, \theta$, dan $\rho_{\mathrm{pr} \cdot \mathrm{Dpr}}{ }^{3} / \mathrm{Q}_{\mathrm{i}} \cdot \theta$, dimana persentase pengaruh masing-masing dimensionless product tersebut terhadap $\mathrm{Ka}$ berturut-turut $53,27 \%$, 45,39\%, dan 10,13\%. Dari sini dapat diketahui

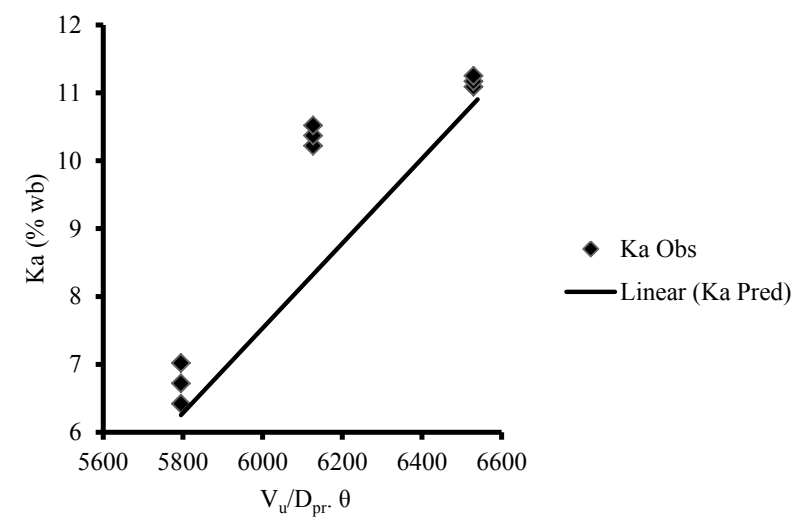

Gambar 4. Grafik hubungan antara $\mathrm{V}_{\mathrm{u}} / \mathrm{D}_{\mathrm{pr}} \cdot \theta$ dengan $\mathrm{Ka}$

bahwa Ka tepung dalam proses pneumatic drying sangat sensitif terhadap perubahan temperatur udara pengering dan temperatur bahan awal yang dikeringkan.

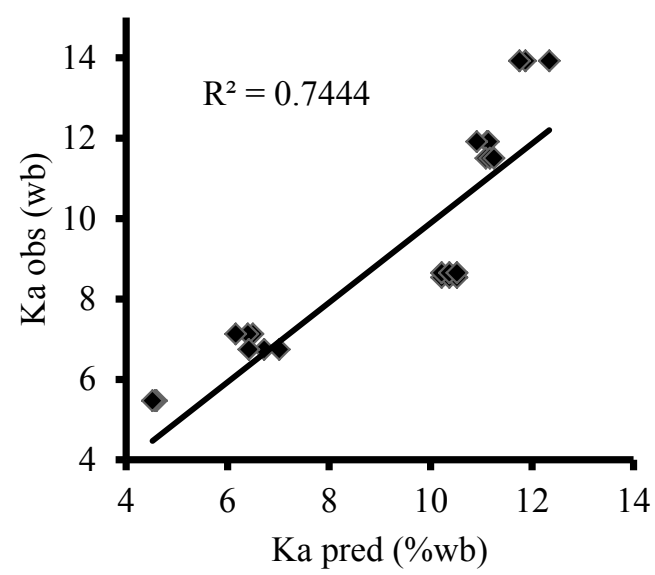

Gambar 5. Grafik hubungan Ka prediksi dengan Ka obervasi

Dengan menggunakan persamaan (11), maka dapat dilakukan perhitungan untuk menentukan nilai $\mathrm{Ka}$ bahan yang dikeringkan. Perbandingan antara nilai Ka prediksi

Tabel 2. Hasil uji sensitivitas Ka

\begin{tabular}{|c|c|c|c|c|c|}
\hline $\begin{array}{l}\text { Dimensionless } \\
\text { product }\end{array}$ & $\begin{array}{c}\text { Penambahan } \\
\text { nilai } 10 \%\end{array}$ & $\begin{array}{c}\text { Persentase perubahan } \\
\text { Ka rata-rata }(\%)\end{array}$ & $\begin{array}{l}\text { Pengurangan } \\
\text { nilai } 10 \%\end{array}$ & $\begin{array}{c}\text { Persentase perubahan } \\
\text { Ka rata-rata }(\%)\end{array}$ & $\begin{array}{c}\text { Rata-rata perubahan } \\
\mathrm{Ka}(\%)\end{array}$ \\
\hline \multirow{3}{*}{$\rho_{\mathrm{pr}} \cdot \mathrm{D}_{\mathrm{pr}}^{3} / \mathrm{Q}_{\mathrm{i}} \cdot \theta$} & 10,13 & & 10,13 & \multirow{3}{*}{10,13} & \multirow{3}{*}{10,13} \\
\hline & 10,13 & 10,13 & 10,13 & & \\
\hline & 10,13 & & 10,13 & & \\
\hline \multirow{3}{*}{$\mathrm{T}_{\mathrm{u}} / \mathrm{T}_{\mathrm{bo}}$} & $-37,73$ & & 68,81 & \multirow{3}{*}{68,81} & \multirow{3}{*}{53,27} \\
\hline & $-37,73$ & $-37,73$ & 68,81 & & \\
\hline & $-37,73$ & & 68,81 & & \\
\hline \multirow{3}{*}{$\mathrm{V}_{\mathrm{u}} / \mathrm{D}_{\mathrm{pr}} \cdot \theta$} & 53,19 & & $-37,59$ & \multirow{3}{*}{$-37,59$} & \multirow{3}{*}{45,39} \\
\hline & 53,19 & 53,19 & $-37,59$ & & \\
\hline & 53,19 & & $-37,59$ & & \\
\hline
\end{tabular}


dengan persamaan (8) dengan nilai Ka tepung yang diukur secara langsung dengan kondisi lingkungan suhu $29{ }^{\circ} \mathrm{C}$ dan kelembaban relative $70 \%$ dapat dilihat pada Gambar 5 . Dari gambar tersebut dapat dilihat bahwa nilai-nilai kadar air hasil prediksi relatif mampu memperkirakan nilai $\mathrm{Ka}$ hasil observasi, dimana kedekatannya dapat dilihat dari nilai koefisien determinasi yang relatif tinggi $(0,722)$. Dari hasil ini diharapkan bahwa persamaan (11) tersebut akan dapat digunakan untuk memprediksi nilai Ka bahan hasil pengeringan pneumatik dengan cukup baik.

\section{KESIMPULAN}

Berdasarkan hasil penelitian, maka dapat disimpulkan bahwa Ka tepung hasil pengeringan pneumatik dipengaruhi oleh berbagai faktor antara lain $\rho_{p r}, Q_{i}, T_{b o}, T_{u}, D_{p r}, \theta$ dan dan $\mathrm{V}_{\mathrm{u}}$. Secara matematis hubungan antara variabel-variabel tersebut degan nilai $\mathrm{Ka}$ tepung hasil pengeringan dapat diformulasikan denganmenerapkan analisis dimensi dalam bentuk hubungan fungsional sebagai berikut,

$$
K a=1,1968 \times 10^{-5} \cdot\left(\frac{\rho_{p r} D_{p r}^{3}}{Q_{i} \theta}\right)^{1.0121}\left(\frac{T_{u}}{T_{b}}\right)^{-4.9698}\left(\frac{V_{u}}{D_{p r} \theta}\right)^{4.4752}
$$

Dimensionalles product yang paling berpengaruh terhadap kadar air pada persamaan tersebut adalah $\left(\frac{T_{u}}{T_{b}}\right)$. Persamaan tersebut berlaku untuk nilai $\left(\frac{\rho_{p r} D_{p r}^{3}}{Q_{r} \theta}\right)$ dari $-7,280-$ $-7,500,\left(\frac{\rho_{p r} D_{r}^{3}}{Q_{i} \theta}\right)$ dari $0,673-0,755, \operatorname{dan}\left(\frac{v_{u}}{D_{p r} \theta}\right)$ dari $3,763-3,815$.

\section{UCAPAN TERIMA KASIH}

Peneliti mengucapkan terima kasih kepada pihak-pihak yang telah berkontribusi dalam penelitian ini, khususnya kepada dosen pembimbing dan anggota LaboratoriumTLBPFPT-UGM dan Laboratorium EMP-FPT-UGM atas segala dukungan tenaga dan pemikiran yang telah diberikan sehingga penelitian ini dapat dilaksanakan dengan baik.

\section{DAFTAR PUSTAKA}

Afrianti, L.H. (2005). Teknologi Pengawetan Pangan. Penerbit Alfabeta,Bandung.

Asosiasi Produsen Tepung Indonesia (2013). Terigu impor terus dibendung. http://www.Aptindo.or.id/berita/terigu impor terus dibendung. [20 Maret 2013].

Asosiasi Produsen Tepung Terigu Indonesia (2012). Produksi terigu diproyeksi naik 2 juta ton, http://www.Aptindo. or.id/artikel/produksi terigu diproyeksi naik 2 juta ton. [7 Mei 2012].

Badan Standardisasi Nasional (2012). SNI 01-2997-1996, SNI tepung singkong (cassava flour).http://www.sisni. bsn.go.id/SNI01-2997-199ㅌ. [7 Mei 2012].

Bunyawanichakul, P., Walker, J.E., Sargison, J.E. dan Doe, P.E. (2007). Modelling and simulation of paddy grain (rice) drying in a simple pneumatic dryer. Journal of Biosystems Engineering 96(3): 335-344.

Desrosier, N.W. (2008). Teknologi Pengawetan Bahan. Edisi ketiga. Penerbit Universitas Indonesia, Jakarta.

Goula, A.M. dan Adamopoulos, K.G. (2005). Spray drying of tomato pulp in dehumidified air: II. The effect on powder properties. Journal of Food Engineering 66: 35-42.

Langhaar, H.L. (1967). Dimensional Analysis and Theory of Models. A.I.T., Library, Jhon Wiley and Sons, Inc, New York.

Stoess, H.A.J.R.P.E. (1983). Pneumatic Conveying, 2 ${ }^{\text {nd }}$, A Wiley-Interscience Publication, John Wilay and Sons, New York.

Zare, D., Ranjbaran, M., Niakousari, M. dan Javidi, M. (2012). Thin layer drying and equilibrium moisture content equations for canola (Brassica napus L.). Iran Agricultural Research 31(1): 11-20. 